\title{
The sadist housewife
}

\section{Asta Lindgren and the Swedish business of pornographic literature in the late 1960 s}

\author{
Klara Arnberg
}

There was a commercial boom of pornographic magazines and films in Scandinavia in the late 1960 s. $^{1}$ Parallel to this, however, there was a growing market for pornographic literature that is often forgotten in historical accounts. Unlike most Swedish books in this genre, the two volumes of Sadistiskt övergrepp ('Sadist assault') became the object of a prosecution for obscene content in the summer of 1967. Since the author was anonymous (writing under the pseudonym Asta Lindgren), the publisher was first held accountable for the books. ${ }^{2}$ When he was about to be sentenced, however, the author-a 22-year-old woman-came forward, and she instead was convicted. This case study follows the criminal case of Sadistiskt övergrepp and the associated media debate, in which Asta Lindgren was described as an ordinary housewife who secretly wrote sadist pornography in her spare time. The case is a prism through which the publication and the sale of forbidden literature, and of the censorial practices involved, is studied. ${ }^{3}$

Since pornographic publishing was partly underground in the period before deregulation in 1971, historical sources describing the publishing contexts of pornographic literature are scarce. The case of Sadistiskt övergrepp is different since the source material from the police investigations and trials provides an insight into how publishers and authors dealt with the legal restrictions, how 
they defended their occupation, and how both authorities and market players negotiated the boundary between the accepted and the pornographic. ${ }^{4}$ The way that the press and the legal authorities made sense of the fact that a woman had written a novel filled with sadism, also gives insights into how notions of pornography and sexual fantasy and needs were gendered. This spilt over into how the business of pornography - at the time often seen as the ugliest face of capitalism-was interpreted.

\section{Pornographic literature in Scandinavia}

Sadistiskt övergrepp connected to a longer discussion about sexual content in Scandinavian literature. When the Norwegian book Sangen om den røde rubin by Agnar Mykle (1957) was prosecuted and found illegal by the Norwegian courts, it spurred a discussion of the obscenity laws in Sweden too. The trial had broken the silent agreement that artistic works would be spared trial, and the way the Swedish legislation was designed-with regional freedom of the press juries that were intended to represent the common notion of decency-made it vulnerable to criticism. It was a lottery if the accused was considered 'a whoremaster [horkarl] or a cultural personality', according to one of the largest newspapers. ${ }^{5}$

Lena Lennerhed has argued that although criticism of the obscenity legislation was not new when it intensified as part of the sexual debate in the 1960s, the methods of critique were. ${ }^{6}$ They included well-known people, or 'cultural personalities', challenging the obscenity legislation in their artistic production. When prominent film directors such as Ingmar Bergman and Vilgot Sjöman tested the boundaries with the likes of Tystnaden (1963) and 491 (1964), they also paved the way for increasingly explicit images in film in general. ${ }^{7}$ For printed pornography, the parallel was the erotic book series Kärlek ('Love'), a pioneer in the market for explicit textual publications (both literature and magazines). ${ }^{8}$ The series-which ultimately numbered fourteen anthologies of short stories authored by cultural figures and edited by the radical 
author Bengt Anderberg-was widely spread and debated, but was not subject to prosecution. ${ }^{9}$ Although Anderberg's objective was to advocate 'good' pornography as an alternative to what he considered rubbishy commercial publications, porn publishers took the inaction of the authorities as a green light for sexual explicitness in text. ${ }^{10}$

Starting in 1967, the Minister of Justice Herman Kling instigated a clampdown on porn. In addition to numerous foreign and Swedish magazine publishers, Asta Lindgren was among those charged. This 'porn raid' was seen as paradoxical given the failure of the authorities to act over the Kärlek series, and because a governmental committee had been appointed specifically to investigate the possibilities of abolishing the obscenity clause. Kling was asked about this in a TV interview. When the reporter asked if he had changed his mind about not prosecuting 'simple sexuality', Kling replied that the magazines had become more brutal (förråande) and 'the two seized books, they are pure sadism'. This was taken to justify proceeding with legal action in anticipation of any legal amendments. ${ }^{11}$ With the subsequent legalization of pornography in 1971, Sweden became the second country in the world to do so (after Denmark 1967 for text and 1969 for pictures). ${ }^{12}$

Sadistiskt övergrepp was clearly part of an upsurge in Swedish porn literature, but the nature and the scale of the market has yet to be studied. A handful of accounts, however, give a hint. The government freedom of the press committee wrote in their report in 1969 that this type of literature was a huge success in 1965 when Kärlek was published (the first two volumes had print runs of 160,000 each), but that the genre had diminished since. ${ }^{13}$ Berl Kutchinsky, who studied the Danish market for the US Presidential Commission on Obscenity and Pornography, detected a wave of pornographic literature between 1963 and 1968, with a peak of 1.4 million copies produced in 1967 (the year of deregulation), and found the same pattern for picture magazines, with an upturn in sales that started five years before the repeal of the criminal law and dwindled the year after. He thus concluded that the repeal of 
the two bans were consequences of the waves rather than their cause. ${ }^{14}$ This suggests that the legislative bodies reacted to the market rather than vice versa.

\section{Pornography as a forbidden genre}

The definition of pornography cannot be detached from its illegality, as Walter Kendrick has argued. Pornography is therefore per definition a condemned and inhibited sexual manifestation-in Kendrick's words, 'pornography names an argument, not a thing. ${ }^{15}$ In the case studied here, different societal institutions such as the legal system and the press, along with the actual business actors, negotiated the limits of decency, and thus the possibilities of pornography as a business. In order to understand this negotiation, Gayle Rubin's seminal text 'Thinking sex' is used as an analytical tool. Rubin argues that modern Western societies inherit a hierarchical system of sexual values. In what she terms the 'charmed circle', the sexuality that is privileged by society can be found. This sexuality is seen as good, normal, natural, and blessed and consists of sexual expressions that are heterosexual, married, monogamous, procreative, free, coupled, in a relationship, same generation, bodies only, vanilla, at home, and with no pornography. Outside of the charmed circle, Rubin draws 'the outer limits' where condemned sexual expressions or acts can be found. These are seen as bad, abnormal, and damned and consist of homosexual, in sin, promiscuous, non-procreative, for money, alone or in groups, causal, cross-generational, with manufactured objects, sadomasochistic, in the park, and with pornography. Rubin argues that there is an enduring struggle to draw the line between good and bad sex in order to maintain sexual order. One of these struggles is the prohibition of sexual commerce in various forms. The criminality of sex-oriented business, Rubin argues, has made it marginal and underdeveloped, and forced it to operate using legal loopholes. ${ }^{16}$

In 1967 , pornography was about to be decriminalized in Sweden. Pornographic publishing was still illegal and relied on legal 
loopholes, but it was seen as anything but marginal and underdeveloped. However, compared to the international porn industry latterly, it was limited to small, partly underground enterprises. ${ }^{17}$ Before considering law and business in relation to sexual values, however, I will turn to the content of the novels.

\section{Reading Sadistiskt övergrepp}

The Sadistiskt övergrepp books are paperback editions, each 92 pages long. ${ }^{18}$ From a reading of the books, it is apparent that the division of the text into two volumes has nothing to do with the narrative; rather, the ending of the first book comes abruptly, and the second book starts without any preamble or introduction of the main characters. The reasons for this may have been practical, for example being able to send them in the post without attracting the attention of customs staff or the like, but could also have been commercial, as two volumes could command a higher price. From contemporary adverts for other books in the same genre, it is plain that the division of pornographic novels into two parts was customary.

The front covers of Sadistiskt övergrepp are quite simple, with stripes and the titles in block letters. The back blurb (identical for both volumes) promises a 'horrible document of some people's ability to transform their most hideous thoughts into reality'. It is said to be based on reality, but written in such a way that individuals would not be recognizable. The story, which spans both books, is said to be based on how young girls - 'not yet even 15'-are forced to accept sexual and sadistic assaults 'no normal human could ever imagine possible. ${ }^{19}$ The back cover and the use of a first-person narrative by a female pseudonym invoke a feeling of authenticity and confession - thus revealing the 'truth' of female sexual vulnerability - that has a long tradition in pornography. ${ }^{20}$

Sadistiskt övergrepp is a first-person narrative about a teenage girl called Britt who lives in a Stockholm suburb with her mother. It starts with a violent rape scene where the protagonist and six of her friends (12-13 years old) are the victims of violent physical experiments 
by a gang of boys. The scene involves objects like tweezers, sticks, bottles, and electric tools, and tissues are used to silence the girls. The section is narrated in an explicit mode from the frightened Britt's perspective. After the rape, the reader follows Britt down a slippery slope in the Rubinian sense. She is raped by her stepfather, she has sex with one of her girl friends, with whom she ends up at a home orgy and is lured into an underground brothel run by a middle-aged couple. There, the girls are terrified and tortured in sadistic experiments. Eventually, the brothel owners are arrested and the girls are transferred to a hospital. With a kiss from her doctor, Britt claims to have been cured from her fear of men that she developed from her experiences. Britt returns to her mother and the stepfather (now forgiven for the rape). In the final pages, the doctor picks Britt up by car (so that she would not have to take the metro and bus into town). After the concluding sex scene-including kissing, mutual orgasms, and penetration - the doctor announces, 'From now on you are an ordinary girl, Britt; you no longer have to be afraid of men.'21

With the gang rape, Britt is forced to the outer limits of Gayle Rubin's circle, into sadomasochism, homosexuality, sex for money, and with objects. When she is saved and cured by the doctor, she enters the charmed circle of good, normal, natural sexuality. Although the sex is neither sanctioned by marriage, nor procreative, or same generation, the narrative makes her prospects of having those sexual relations later in life seem plausible. Thus, the bad, sinful outer limits of the circle are described in detail in the novels, but are carefully dismissed as pathological in the happy ending. However, the lesbian sex scenes do not follow the script of being only a 'warm-up' for heterosexual intercourse. ${ }^{22}$ Apart from the final scene, these are the only instances when Britt experiences pleasure without fear. After the tender sex scene with her girlfriend, Britt exclaims: 'Imagine if all men could be this wonderful, but I guess that's too much to ask.'23 However, in the full story everything leads up to the salvation of heterosexual intercourse. By using prostitution as a theme, Sadistiskt övergrepp is also pornographic in the literal sense of the word-it is a text about prostitution. ${ }^{24}$ 
In the narrative, the hierarchies of sex are coupled with hierarchies of social class. Britt and her friend are emblematic of the perceived contemporary problems of young suburbanites, having divorced parents, consuming alcohol at a young age, and being the victims of sexual violence. The middle-class people they meet use Britt and her friend's lack of power relative to their class, gender, and age. Just as in sexploitation films and romance literature of the same period, the good middle-class knight personified by the doctor saves Britt from her desperate situation. He finally guides her into the 'right' heterosexual desire.

\section{Circumventing censorship: The importance of timing}

The pornography laws in 1967 were divided into two: one came under general film censorship, the other was an Article in the Freedom of the Press Act with a related section in the Criminal Code. Unlike film censorship, the Swedish freedom of the press legislation stipulated that one copy of everything published had to be sent to a regional freedom of the press representative at the time of publication (not in advance). This representative would then report any obscene material to the Minister of Justice. The minister, in turn, would pass it to the Chancellor of Justice to take legal action. In such cases, a seizure order was issued until the final verdict (thus halting the sale). There were three court cases concerning Sadistiskt övergrepp: one about the Swedish edition, one about the practicalities of printing and inspection copies, and one about the German edition of the book. ${ }^{25}$

According to the police reports, the publisher Alf V paid 2,000 kronor (equaling a little more than five weeks' salary for female workers as a comparison) for Asta Lindgren's manuscripts in the winter of $1966-7$ on condition of not revealing her true identity. ${ }^{26}$ The books were published on 25 April 1967. That day, the publishing house, Vänerförlaget, sent 2,500 of its 8,420 copies to a wholesaler in Stockholm for further distribution; the rest-apart from the later confiscated 3,855 copies-were sent to wholesalers, tobacconists, 
and bookshops across the country, and some were sold by mail order. This meant that over half the copies had been sold before the seizure order on 13 July. ${ }^{27}$ Intentional or not, the timing of the submission of the inspection copy was important for sales. ${ }^{28}$

When Alf $\mathrm{V}$ was informed of the official decision that he would be responsible in the absence of the author, he met Asta Lindgren and asked her to come forward. They both stressed that he had not forced her to do so, but she was paid 500 kronor and an additional 100 kronor as a fee from Alf V. She considered it unjust to make someone else suffer for something she had written, she explained to the court. If she were acquitted, Alf $\mathrm{V}$ had promised her 1 krona extra per book sold, and he covered her travel costs. ${ }^{29}$

The freedom of the press jury found Asta Lindgren guilty on all charges, since the content of the books was found to be 'exceptionally sadistic and brutal'. She was sentenced to a month in prison. ${ }^{30}$ In the parallel case, the printer and the publisher were fined for failing to submit an inspection copy on time and for printing misleading information about the year of printing, as the first volume had 1966 instead of 1967, and the second gave no date. ${ }^{31}$ (Both these omissions were commonly used strategies to ensure publications survived long enough to sell. ${ }^{32}$ ) Asta Lindgren and her lawyer said they were shocked by the verdict. All comparable cases had ended in fines. They immediately said they would appeal, even if only to change the sentence. Asta Lindgren had prepared to be fined, and had obtained financial compensation from the publisher to cover it. In the press, it was also explicitly suggested that one reason why Lindgren had come forward was a financial calculation of who would get the lowest fines (in a system based on incomes, dagsböter): 'the housewife or the successful porn publisher. ${ }^{33}$

The prosecutor defended Lindgren's imprisonment: 'The books are filled with acts of torture against young girls. Women are treated like dimwits and most of the content is written in an abnormal way. ${ }^{34}$ In the Court of Appeal, Svea hovrätt, however, Asta Lindgren's penalty was reduced to fines only. ${ }^{35}$ Neither Lindgren nor the Chancellor of Justice appealed to the Supreme Court. 
Only the following year, in 1968, there was a new freedom of the press case, this time concerning the German edition of the first book, Sadistische Übergriffe Teil 1. The dramatic turns were similar to the previous case, with a prosecution decision to pursue the publisher in the absence of the author, and then a letter in which Asta Lindgren agreed to take responsibility for the work. Despite this, however, the police investigation concluded that the German edition had been published without the author's permission, and hence she could not be held accountable for its content. The prosecution case was rejected in the autumn of $1970 .{ }^{36}$

Even if pornography publishing mainly consisted of small enterprises, the production and sale of the German edition showed that international distribution networks were operating as early as the 1960 s. In the spring of 1967 , Alf V signed an agreement with the Danish firm Rodox Trading for a German translation, and once printed in late June 1967 all 6,000 copies were dispatched to Copenhagen. The order to seize the books did not come until 14 October 1968 , by when the police could find only a single copy.

\section{Advertising pornography}

Pornography in the 1960 s was not only censored and circumscribed in a legal sense. It was also precluded from general business agreements. Most notably, items that were considered pornographic were denied access to ordinary distribution channels, and, for porn magazines, found it difficult to attract advertisers outside sexual commerce. ${ }^{37}$ Later, when the anti-pornography movement grew stronger in the 1970 and 1980 s, ordinary daily and evening papers started to refuse adverts from the porn trade; in the late 1960s, however, especially the sports pages of evening newspapers were filled with adverts for sex clubs, porn retailers, and various pornographic publications. ${ }^{38}$ In this way, some of the ordinary market actors were in fact sanctioning the porn trade.

A newspaper search reveals that Sadistiskt övergrepp was first 


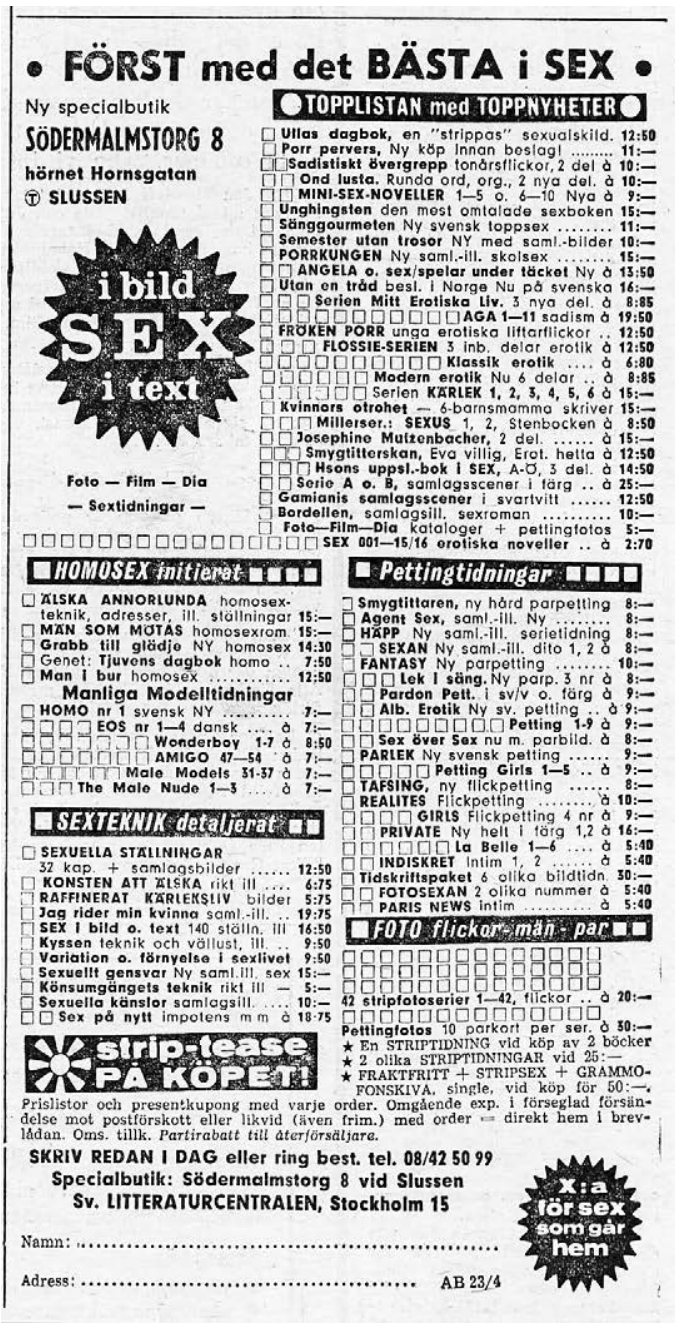

Figure 3.1 Sadistiskt övergrepp, advertised in Aftonbladet, 23 April 1967, 25.

advertised on 23 April-two days before it was published (Fig. 3.1). It was third in a 'top list with top news' from a Stockholm sex shop. The advert was printed as a product list that could also be used to order from the wholesaler Svenska Litteraturcentralen (Swedish Literature Central) for home delivery. Annonsbokhandeln 


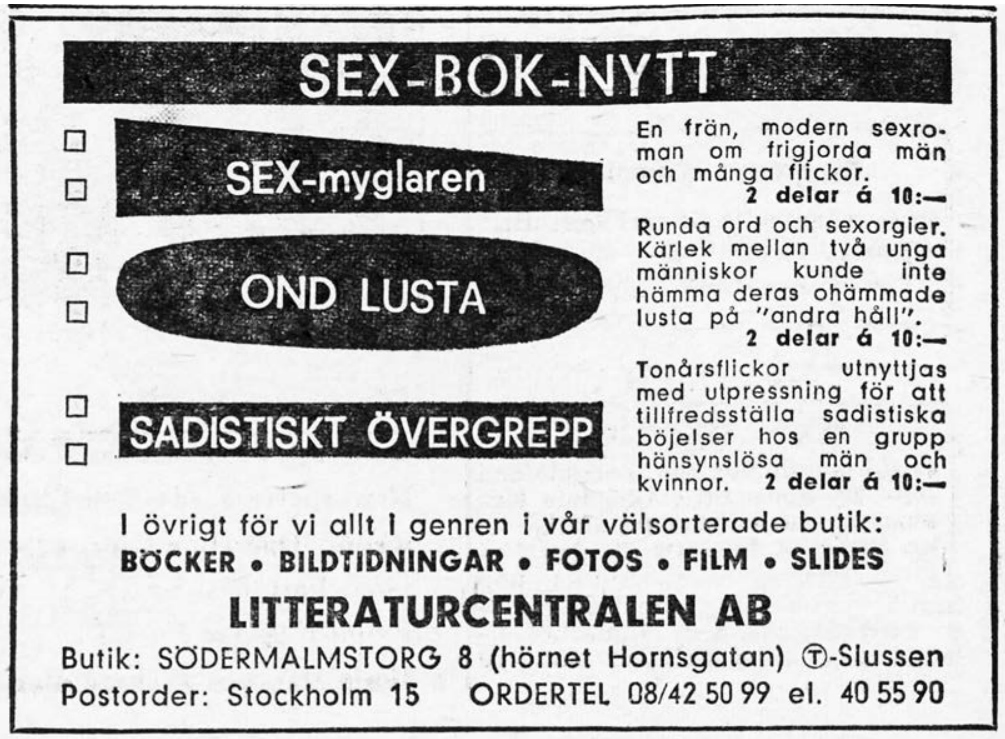

Figure 3.2 Advertisement for Sadistiskt övergrepp, Aftonbladet, 13 May $1967,24$.

(Advertisement Bookshop) in Vänersborg also advertised the books, and while it was only probably connected to Alf V's business, Svenska Litteraturcentralen definitely was: Vänerförlaget and Svenska Litteraturcentralen had a joint stock company together under the name Litteraturförlagen AB (Literature Publishers Ltd) until late $1967 .{ }^{39}$

Adverts for the books were published every week until 2 July and included a mail-order firm in Norrköping, Europa Press Agentur (European Press Agency) in Gothenburg (with nearby shops) and the Frigga bookshop in Gothenburg. With time, adverts tended to appear on Sundays. It is important to note, however, that most of the adverts promoted several books and magazines, not Sadistiskt övergrepp alone. In an advert published several times in the second half of May, Sadistiskt övergrepp was advertised alongside only two other books (Fig. 3.2). In this advert, the content of the books was described in a little more detail than otherwise: 'Teenage girls are exploited with extortion to satisfy the sadistic addiction of a group of unscrupulous men and women.' The other two books advertised 
Figure 3.3 Advertisement, Expressen, 18 July 1967, 22.

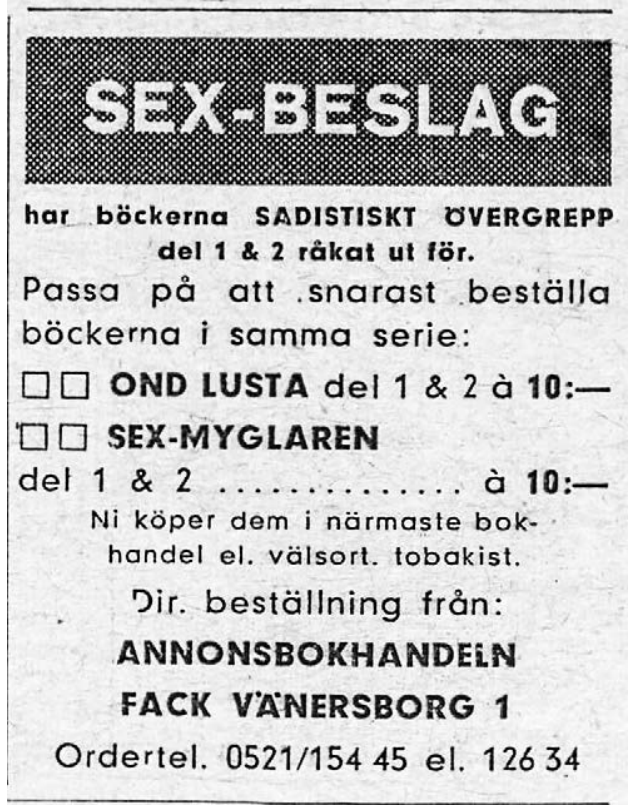

were also divided into two parts, costing 10 kronor each. Litteraturcentralen also offered a free striptease magazine when ordering two books. ${ }^{40}$ Several books were advertised in direct relation to the legislation: 'New, buy before seizure' or 'Seized in Norway, now in Swedish. ${ }^{41}$ In this way, the (possible or actual) seizures were used as sign of pornographic value in the Kendrickian sense, and thus a useful selling point. The advertising of Sadistiskt övergrepp ended with their seizure in July, but likewise became an argument when selling other books with similar content. One advert from Annonsbokhandeln read 'Sex-seizure' and the reader was told to grab the opportunity to order books in the same series: Ond lusta parts 1 and 2 and Sex-myglaren parts 1 and 2 (Fig. 3.3). When Lindgren was first convicted, the Frigga bookshop placed a similar advert, announcing that 'IMPRISONMENT is the sentence given to the 23-yearold authoress of Sadistiskt övergrepp. Today, we can offer a short story written by the same girl. Sex oo19-20, now only 6 kronor. ${ }^{2}$ Here, the court case was explicitly used to sell the publications. A prison sentence became the hallmark of pornographic authorship. 


\section{Social realism or literary fantasy?}

The negotiations of the limits of decency were vivid in both the court and in the press. These negotiations clearly related to the perceived erosion of these limits. When Kling passed the case to the prosecution service, Alf $\mathrm{V}$ was quoted in the press accusing the authorities of basing their decisions on a nineteenth-century world view. New liberal opinions of pornographic literature had guided his decision to publish, and the news that he now risked up to six months' imprisonment was 'a bolt from the blue', as he put it, especially since Kling had previously indicated that the publication of pornographic books would not be regulated by 'outmoded articles' in the law. ${ }^{43}$

Another way of defending the books was to compare them to other publications on the market. Alf $\mathrm{V}$ did not consider the content obscene compared to previous legal decisions, especially in relation to cheap crime novels sold in ordinary kiosks (Pressbyrån) 'with murder, knife fights, rape and other fictional crudity on every other page'. Against this, Alf V stressed the social realism and authenticity (based on the true experiences of the author) of Sadistiskt övergrepp: 'Are we no longer allowed to publish depictions of life itself?' Alf V protested. ${ }^{44}$ According to him, the books highlighted the suffering of young people-children even-without the knowledge of their parents or the authorities. Therefore, he thought the contents should be interpreted as a warning. In this way, Alf V continued to market the books in a way that corresponded to both the back blurbs and the adverts, which offered the supposed truth about the sexuality of socially depraved young girls. Asta Lindgren did not take the same authenticity track as Alf V, though. Both in court and the press, she underlined that the stories were pure fantasy and nothing she had experienced herself. However, she claimed to have read a good deal of similar literature.

The defence used comparisons to other publications on the market in order to prove that the seizure of Sadistiskt övergrepp was inequitable. In a letter to the Department of Justice, Alf V's lawyer asked 
whether the 1966 Swedish translation of Guillaume Apollinaire's pornographic novel Les onze mille verges (1907) had been approved by the authorities. The deputy director of the department responded that they could not read everything in detail, and that a book on the market that had not been subject to prosecution should not be thought 'approved'. Also, they had to consider the risk of bringing further publicity to the publication by their actions. ${ }^{45}$ This indicates that the legal border between acceptable and pornographic was blurred, and that the authorities were tactical rather than consistent in their approach to the growing market for pornographic publications. They were well aware that a prosecution would lead to media attention, and in that way also to increased demand. Alf $\mathrm{V}$ did not hesitate to mock the authorities in the media for the failure of their tactics-'It is clear that this is the way to make a book known. But I guess that was not what the Minister of Justice intended'-and claimed not to understand why legal action took so long; almost the whole edition had sold out by the time it was seized. ${ }^{46}$

In court, Asta Lindgren's lawyer invoked what he termed comparable literature, and read passages not only from Apollinaire, but also Nine Christine Jönsson (who had written pieces in the Kärlek series), Johnny Bode-Delgada (author of several erotic novels and often described as an enfant terrible of Swedish culture), and Lars Görling (whose novel 491 was the basis for a film of the same name that was banned for its sexual and brutal content, and later released, cut, in 1964). ${ }^{47}$ The defence placed Lindgren's texts in a literary canon on the verges of respectability, but perhaps more importantly among known and more accepted authors.

\section{Poor housewife, successful porn publisher}

Asta Lindgren was 22 and working as a secretary when Sadistiskt övergrepp was published. She lived in the small city of Helsingborg, but just like her protagonist Britt she had been brought up by her single mother in a Stockholm suburb. Given this, Lindgren's characterization in the mass media was paradoxical. Instead of 
retailing the authenticity narrative put forward by Alf V, Lindgren was instead repeatedly described as a housewife and a woman of a certain age (tant). One newspaper even had her age as 42. Asta was a popular girl's name in the 1910 and 1920 , and thus associated with middle-aged women in the $1960 s .{ }^{48}$ Her pseudonym's intended or unintended resemblance to the beloved writer of children's books, Astrid Lindgren (born in 1907), might also have spawned associations to a more middle-aged, warm, maternal femininity. Asta Lindgren was portrayed as having a dual nature, telling fairytales to children and writing tender love stories by day and authoring sadistic pornography by night. She was living with her husband in a 'neat two-room flat', and their normality and respectability in terms of sexual hierarchies were further emphasized by Lindgren's statement that 'My husband and I have a normal sexual life. Neither of us is a sadist or a masochist. I am not a lesbian and my husband is not a homosexual.' 49

Lindgren claimed it all started when she began reading the literature her husband was interested in, at first with aversion, but then with increasing fascination. She found porn literature to be dull and featureless, but also expensive. In order to save money, she therefore started to write porn novels for her husband. In several instances, she stressed not to get any sexual satisfaction from writing the stories-vulgar sexual expressions disgusted her, and writing them down left her indifferent. Her only source of inspiration was her own lively imagination, guided by her husband's wishes. She claimed she only decided to sell the manuscript because of their financial situation. ${ }^{50} \mathrm{With}$ the help of sensation-seeking journalism, Lindgren thus framed herself as an innocent in a wider moral sense. She wrote the books from inside matrimony, in order to fulfil her husband's - not her own-sexual needs. The decision both to write and to publish the books also stemmed from financial need rather than greed, adding to the image of innocence.

Alf $\mathrm{V}$ was presented as Lindgren's opposite both in court and in the press. If she was framed as unknowing and harmless, he was the calculating businessman in a shady trade. Alf $\mathrm{V}$ was 40 years 
old in the spring of 1967 , and married with two small children. He had worked with book publishing since the 1950 s and had run Vänerförlaget since 1963. Even if Alf V is not one of the bestknown Swedish pornographers, he was certainly one of the main underground porn dealers at the time. By studying the court cases from the 'porn raid', it becomes clear that Alf V acted as a wholesaler and distributor of pornographic publications. ${ }^{51} \mathrm{He}$ was also open about his business in public, although from the various court cases it seems he often chose to have others act on his behalf. In several cases, the police investigation suggested that the defendants were in fact frontmen, and many had been in financial difficulties when they agreed to publish or distribute pornographic books or magazines on Alf V's behalf. ${ }^{52}$

Alf V was described as a crafty if astute businessman in the press. It was said he did not have the look of a porn baron, but rather a civil servant or a teacher. One newspaper talked of the risks of his business as a pornography wholesaler, with his stock always liable to seizure, which could lose him up to 100,000 kronor a year. Pornography was expensive, he said, not because of greedy businessmen but because distribution costs were so high: ordinary distribution channels were closed to the porn trade, so they had to build their own to manage the 5 million books and magazines said to be sold every year in the Swedish porn market. There was no shortage of writers-even well-known authors were writing under pseudonyms - and some titles were translations. ${ }^{53}$

In the preliminary investigations for the trial of the German edition, the relationship between the publisher and the author were dealt with in detail. Lindgren said that Alf V had approached her at the main hearing in the Court of Appeal (for the Swedish edition of the book) and wanted her to sign an agreement where she would come forward as the author of the German edition too. By then the translation was complete and the books sent abroad. She refused to sign, but then Alf V and his wife visited Lindgren and her husband unannounced in February 1969. Alf V tried to convince her that the court would most certainly withdraw the case, 
and that both his lawyer and two prosecutors had confirmed that there was a loophole in the law that they could use. He offered her 1,000 kronor for coming forward a second time, and 400 kronor for her court fines for the Swedish version. He said she could get the money immediately if only she signed. Lindgren was unwilling to do so before speaking to her lawyer, but Alf $\mathrm{V}$ advised her not to ring him since he would certainly consider the offer a bribe. According to Lindgren, her own husband had then said: 'Well, that's exactly what it is', whereupon Alf V's wife became angry. The Lindgrens were presented as vulnerable by their defence-she had just come home after abdominal surgery and her husband was on sick leave due to mental illness-and in financial strains again, with only two cigarettes left, unpaid bills including the rent, and barely enough food for the day. These circumstances made Lindgren agree to sign. She was immediately given cash and a cheque, Alf $\mathrm{V}$ gave them cigarettes, and then he took them out to lunch. In Alf V's version, however, he did not have the impression that the Lindgrens were cash-strapped, and his payment to Lindgren was an advance for another manuscript.

In January 1968 Asta Lindgren was interviewed in a magazine called Personligt ('Personal') where for the first time she revealed her real name and photograph. The trial was described as a 'witch-hunt' and the Personligt front cover announced its exclusive interview with her. The magazine was published by Thord Åkerlund, another of Vänersborg's pornography associates with close connections to Alf $\mathrm{V}$. The interview carried adverts for Annonsbokhandeln and for one new book in particular-Sex i Linköping-with the customary slogan of 'Buy now-Buy soon-Buy before it’s seized.' It was Åkerlund who interviewed Lindgren, under the headline 'Beautiful but frightened'. It begins by using her looks to argue for the absurdity of sentencing her to jail. 'Does she look like a devastator of youth and morality? Does she look like a witch?' No, the article continued, but she had nevertheless fallen victim to a witch-hunt, sentenced under the same old laws that were used to burn women at the stake. ${ }^{54}$

The naming and picturing of the real Asta Lindgren can be seen 
as a new claim to authenticity. She repeated the story of her husband and asserted that neither of them was a pervert. However, unlike on other occasions, she 'admitted' to sexual arousal in the writing process: 'Of course I get-just like other normal people-exceptional feelings of lust when I read pornography' She described the trial as a 'murder of free speech', thus enabling the Swedish democracy to prove its strength to its constituencies. In order to keep morally conservative and religious voters on side in the upcoming election, the Social Democrats were forced to publicly move against the porn trade, according to Lindgren. 'How about the small minority who enjoys reading pornography? Do they not have the right to vote?' She claimed to have been immolated, and the trial had been a pure miscarriage of justice, a 'murder of democracy', she stated (the latter printed in capital letters). 'There is not a single photograph or drawing in the books I have written. Only free words, generated from pure spontaneity and genuine fantasy. ${ }^{55}$

People who bought and read her books knew very well what to expect, she continued, as the titles described the contents. She repeated many of the often-used arguments at the time for more liberal legislation, stating that there was no evidence of a correlation between violent crime and pornography consumption. The welfare state saw no problem in selling alcohol (the state has long had the monopoly) although clear correlations could be proven between violent crime and alcohol. And that she was a front for someone else was pure defamation, she stated in the interview. She claimed to have received no financial compensation for coming forward as the true author. ${ }^{56}$

\section{Concluding discussion}

The Asta Lindgren case highlights how censoring practices can be studied in relation to and as market regulation. The emerging mass market of pornographic publishing put the censorship legislation to the test. The same type of content could be judged differently by different regional freedom of the press juries, and almost all other 
books reached the market without legal review. More importantly, then, the state and its juridical system were not the only censoring actors in a market system: so were publishers (rejecting or accepting different types of texts for publication), advertisers (channeling resources to some publications but eschewing others), distributors (choosing to deliver some publications but not others) and retailers (in their choice of stock). In this way, the market actors set up (articulate or inarticulate) censorship practices that circumscribed the publishing market. In order to fully understand how sexual hierarchies have informed the publication of pornography and vice versa, the whole chain of production has to be studied.

It is clear that Lindgren's publications fell into the unacceptable section of the market in several ways. Her books were sold mainly by porn retailers; they were distributed by networks of porn traders; they were only advertised alongside other porn publications. Her books thus belonged to a section of the market deprecated by mainstream commercial actors. One part of the pornography production chain, however, had access to ordinary commercial channels: pornography publishers used evening newspapers to advertise their publications. This access, however, would eventually come to an end.

The case also highlights that the hierarchy of sexual value and the negotiations about the limits of decency were informed by notions of gender and social class. Lindgren's situation as a wife was important for how she was depicted both in the press and in court. Even if her writings were seen as extremely brutal, on the outer limits of Rubin's circle, Lindgren as a person was portrayed as a harmless innocent. Apparently, it was hard to imagine anyone less likely to be imprisoned for a sex-related crime. Alf V, on the contrary, was an obvious candidate. He appeared as an unscrupulous porn publisher, exploiting vulnerable people for his own ends, and happy to use bribes to get his way. There was also a class aspect to this. Lindgren was not one of the well-known authors often said to work under pseudonyms to get an extra income, and Alf V was not a high-profile cultural personality who sometimes chose to test 
the limits of the legislation. This lack of cultural credibility worked differently for the two, however, for while she ostensibly wrote for pure survival (making her vulnerable), he acted out of self-interest (making him unscrupulous). Neither was framed as having artistic ambitions. Their motives were purely financial. And, tellingly, neither found their defenders in the public debate in the way Vilgot Sjöman did over his film 491, or indeed the authors of Kärlek.

For a few years, both AlfV and Lindgren seem to have stayed in the business. She wrote at least two more books for Vänerförlaget under a new pseudonym (Solveig Källgren). Alf V seems to have moved on to other businesses in the 1970s. According to Swedish tax records, Alf V died in 1980, while Lindgren moved to Denmark in 1976.

My ambition with this text has not been to uncover the 'truth' about Asta Lindgren in the sense of her previous sexual experiences or reasons for writing (or even if she was financially exploited by Alf V). Instead, I illustrate how the 'truth' of female sexuality was used as a selling argument to retail books, both in paid adverts and in the discussion about the books in the press. A historical perspective on Rubin's circle also makes it clear that the nature of sanctioned sexual practices has shifted over time and place. While the detailed descriptions of what are still condemned practices-sexual violence and the torture of children-had led the authorities to draw the line in 1967, other sexual expressions that upset the audience then have now entered into the charmed circle.

The very banning of the books, and the setting up of a limit on decency (or in Lindgren's words, murdering free speech) made the books pornographic in a Kendrickian sense. Official regulations and the actions of the authorities thus stipulated not only the limits of what the pornography publishing industry could become, offering specific loopholes they exploited to the full, but also defined the industry as such. However, the industry did not disappear with deregulation, rather the opposite. Retailers, distributors, and the mass media all continued to use pornography as an argument for censorship practices, and thus for redefinition. 


\section{Notes}

1 See, for example, Stevenson 2010; Larsson 2010, 205-213; Larsson 2007, 93-111; Björklund \& Larsson 2016; Björklund 2012; Arnberg 2010.

2 Guided by the Swedish National Archives' restrictions and the sensitivity of the material, I use only the pseudonym, even though Lindgren herself eventually came forward and used her real name in the press, and for the same reasons I refer to the publisher as 'Alf V', even though he was a public figure.

3 I wish to thank Anna Hultman, Mariah Larsson, and the editors for their valuable comments on previous versions of the text. The research was financed by the Jan Wallander and Tom Hedelius Foundation.

4 See also the contributions of Heede, Schatz-Jakobsen, and Lindsköld in this volume.

5 Lundevall 1958a, cited in Arnberg 2010, 77; see also Lundevall 1958b; Lennerhed 1994, 191.

6 Lennerhed 1994, 189; see also Johansson's contribution in this volume for previous methods of critique.

7 See Lennerhed 1994; Larsson 2017; see also the introduction to the present volume for the tradition of transgression in modern art, and Schatz-Jakobsen in this volume for how the ban was lifted from one such 'cultural personality' in England.

8 Lennerhed 1994; Arnberg 2010; Anderberg 1965.

9 Silbersky \& Nordmark 1969.

10 Nilson 2009, 210-18; Arnberg 2010, 139; Larsson 2007.

11 Swedish television 1967.

12 See Arnberg 2010; Arnberg 2012, 350-77.

13 SOU 1969:38, 55.

14 Kutchinsky \& Snare 1999, 83-5.

15 Kendrick 1996, 31.

16 Rubin 2008, 281-323.

17 See Arnberg 2012.

18 Copies of Sadistiskt övergrepp are not readily available. There are none in the Chancellor of Justice's files, nor are there any in the National Library of Sweden, which otherwise is obliged to keep a copy of everything published in Sweden. Lund University Library, however, holds a copy of each volume.

19 Lindgren 1967a, back jacket; Lindgren 1967b.

20 See, for example, Frappier-Mazur 1988, 112-28; Marcus 1966, 203-204; Williams 1999.

21 Lindgren 1967b, 92.

22 See, for example, Williams 1999, 140.

23 Lindgren 1967a, 40-1.

24 For prostitution in pornographic literature, see Norberg 1993, 225-52. 
25 Riksarkivet (RA) (National Archives of Sweden), Stockholm, Justitiekanslern (JK) (Office of the Chancellor of Justice), Akter till allmänna diariet (Files for the public register) $\mathrm{nr} 247,248$ and 336 (1967) \& nr 345 (1968).

26 Average hourly wage for female manufacturing workers was 8.767 kronor in 1967, and the working week 42.5 hours. See Prado 2010.

27 The number of printed copies varied, with sources sometimes mentioning up to 10,00o copies; see, for example, Pettersson 1967, 6 .

28 Dagens nyheter 1967; Svenska dagbladet 1967; Hudiksvallstidningen 1967.

29 RA, JK, Akter till allmänna diariet nr 247 \& 248 (1967).

30 Verdict in the local court, Vänersborg, 8 December 1967, RA, JK, Akter till allmänna diariet $\mathrm{nr} 247$ \& 248 (1967)

31 Verdict in the local court, 10 December 1968, RA, JK, Akter till allmänna diariet nr 336 (1967).

32 See Arnberg 2010.

33 Expressen $1967 \mathrm{c}$.

34 Expressen 1967b.

35 Verdict in the Court of Appeal of Western Sweden, 6 November 1968, RA, JK, Akter till allmänna diariet nr 247 \& 248 (1967).

36 RA, JK, Akter till allmänna diariet nr 345 (1968).

37 Arnberg 2010 \& 2012.

38 Arnberg 2018.

39 Preliminary investigation notes, 20 March 1968, RA, JK, Akter till allmänna diariet nr 85 (1968).

40 Advert in Expressen, 15 May 1967, 15.

41 See advert for Porr pervers in Expressen, 30 April 1976, 33, and for Utan en tråd in Expressen, 15 May 1967, 96.

42 Advert in Göteborgstidningen, 10 December 1967, 44.

43 Axelsson 1967; Pettersson 1967.

44 Axelsson 1967.

45 Olof Börjesson to Olle Bernling, 21 December 1967, RA, JK, Akter till allmänna diariet $\mathrm{nr} 247$ \& 248 (1967).

46 Axelsson 1967.

47 Verdict in the local court, Vänersborg, 8 December 1967, RA, JK, Akter till allmänna diariet nr 247 \& 248 (1967). See also Lennerhed 2016, 116-25; Nilson 2009.

48 Brylla 2004.

49 Expressen 1967a.

50 Ibid.; Expressen 1967b.

51 See also Michanek 1967.

52 See, for example, RA, JK, Akter till allmänna diariet nr 353 (1968). In one case, however, the lower instance, Rådhusrätten, sentenced Alf V to one month in prison for importing and distributing Danish pornographic magazines. Just as 
for Asta Lindgren, the sentence was reduced to fines by the Court of Appeal; JK 353, 361-363, 396, 397, 414, 415, 418, 447, 448, 465, 476, 479 (1968), and $28,49,68,96,242(1969)$.

53 Karlsson 1968, 14.

54 Åkerlund 1967, 23-48.

55 Ibid. 47.

56 Ibid. 26. 